\title{
Soil Biological and Biochemical Response to Cd Exposure
}

\author{
Reginald Ebhin Masto*, Rajkumar Ahirwar, Joshy George, Lal Chand Ram, \\ Vetrivel Angu Selvi \\ Central Institute of Mining and Fuel Research, Digwadih Campus, Dhanbad, India. \\ Email: mastocfri@yahoo.com \\ Received June $2^{\text {nd }}, 2011$; revised June 20 $0^{\text {th }}, 2011$; accepted June $25^{\text {th }}, 2011$.
}

\begin{abstract}
Though heavy metals can stimulate the activity of soil enzymes in smaller amounts, yet act as inhibitors, if present in high concentrations. Natural and anthropogenic heavy metal contamination and its disturbances on soils can be evaluated by using enzymatic activities as sensors. To study the effects of Cd, soil added with known Cd concentrations $(0,10,20,50,100$ and $200 \mathrm{mg} / \mathrm{kg}$ soil) were incubated for a period of 30 days at $28^{\circ} \mathrm{C}$. At intervals of $0,5,10,20$ and 30 days samples were withdrawn for enzyme assays like dehydrogenase (DHA), catalase (CAT), phenol oxidase (PHE), and peroxidise (PER). In a separate experiment the effect of Cd on active microbial biomass carbon (AMBC), basal soil respiration (BSR), and metabolic quotient were studied. AMBC showed a reduction trend with increase in Cd concentration, and a maximum reduction of $47 \%$ was observed at $30^{\text {th }}$ day for $200 \mathrm{mg} / \mathrm{kg}$ treatment. BSR also showed the same trend, with a maximum decrease of $42 \%$ at the $30^{\text {th }}$ day. With the rate of $\mathrm{Cd}$ amendments and treatment period, DHA showed an inhibition trend; whereas maximum decrease was observed for $200 \mathrm{mg} / \mathrm{kg}$ treatment at $30^{\text {th }}$ day. CAT, PER, and PHE were found to be increased with Cd addition and remained at higher levels than in the control soil. These changes can be attributed to the effect of $\mathrm{Cd}$ on microbial activities. Based on cluster analysis, $\mathrm{AMBC}$ appears to be the sensitive indicators for the soil exposed to Cd contamination.
\end{abstract}

Keywords: Cadmium, Microbial Biomass, Basal Soil Respiration, Dehydrogenase, Catalase, Peroxidase, Phenol Oxidase, Respiration Quotient

\section{Introduction}

Intensified urbanisation and associated anthropogenic activities cause extensive changes on soil and soil-related natural resources. The study of enzymatic activities in soil is a useful tool for assessing the functional diversity of soil microbial communities or soil organic mass turnover (Kandeler et al. 1999). Soil biological activities and biochemical properties get altered with addition of fertilisers, agricultural activities and also with the contamination of chemicals like heavy metals. Soil microbes get influenced by pollutants introduced into the soil, which is manifested by changes in enzyme activities. In this group, heavy metals are of special importance, which can stimulate the activity of soil enzymes in smaller amounts, but can also act as inhibitors if present in high concentrations (Christensen et al., 1982; Frankenbereger et al., 1983; Wyszkowska et al., 2001). In general, an increase of metal concentration influences soil microbial properties (e.g. respiration rate, and enzyme activity), which appear very useful as indicators of soil pollution (Brookes, 1995; Szili-Kovács et al., 1999). In sewage sludge and phosphate fertilisers, $\mathrm{Cd}$ is one of the most toxic and has been recognised as an environmental contaminant of considerable interest in various human and animal diseases (Bramley, 1990; Loganathan et al., 1996). Moreover Cd represents a group of heavy metals causing the most severe changes in the biological properties of soils (Milosevic et al., 1997; Landi et al., 2000; Lebedeva et al., 1995; Welp, 1999; Zheng et al., 1999).

The purpose of the study was to determine the influence of cadmium contamination on soil microbial activities. Soil enzyme activities are the driving force behind all the biochemical transformations occurring in soil. Several soil quality monitoring programs employed microbial biomass, basal respiration, and microbial community structure as indicators of soil environmental quality (Doran and Parkin, 1994; Sparling, 1997, Yao et al., 2000). Soil microbial biomass, which plays an important role in nutrient cycling and ecosystem sustainability, has been found to be sensitive to increased heavy metal concentrations in soils (Giller et al., 1998; Huang and Khan, 1998). Basal respiration is also commonly measured and indicates the total carbon turnover. The metabolic quotient, i.e., the ratio of basal respiration to microbial biomass, is inversely related to the efficiency with which the microbial biomass uses the indigenous substrates (Anderson and Domsch, 1990) and can be a sensitive indicator for revealing heavy metal toxicity under natural conditions (Wardle and Ghani, 1995). Though there are few studies on the effect of $\mathrm{Cd}$ on soil microbial activities, most of them are carried out in temperate soils, where the microbial activities are quiet higher as compared to tropical soils. Such studies on tropical soils are limited. In view of above, this study was undertaken to determine the effect of cadmium exposure on the soil biological activities in a red soil from tropical region of India.

\section{Materials and Methods}

\section{Incubation Experiment}

Soil samples collected from Central Institute of Mining and Fuel Research (CIMFR), Digwadih campus were selected for the study, and analysed for their physico-chemical properties by standard methods and data are shown in Table 1.The samples were passed through $2 \mathrm{~mm}$ sieve, and added with required quantities of cadmium chloride in solution form to attain different $\mathrm{Cd}$ concentrations of $0,10,25,50,100,200 \mathrm{mg} / \mathrm{kg}$ soil. The samples were then incubated at $28^{\circ} \mathrm{C}$, while maintaining 
the moisture content of the soil at field capacity level by adding required amounts of water. Samples were taken out at $0,5,10$, 15,20 , and 30 days of incubation, and analyzed for dehydrogenase, peroxidase, phenol oxidase, and catalase activities. A separate set of soil was incubated for 10 days to measure the soil respiration rate and active microbial biomass.

\section{Methods of Analyses}

Dehydrogenase activity (DHA) was determined by adding $0.2 \mathrm{ml}$ of $3 \%$ sterile triphenyltetrazolium chloride (TTC) solution and $0.5 \mathrm{ml}$ of $1 \%$ sterile glucose into a culture tube containing $1 \mathrm{~g}$ of soil sample. After an incubation period of $24 \mathrm{hr}$ at $28^{\circ} \mathrm{C}, 10 \mathrm{ml}$ of methanol was added and re-incubated at $28^{\circ} \mathrm{C}$ for $8 \mathrm{hr}$. The extracted triphenyl formazan (TPF) was measured by absorbance at $485 \mathrm{~nm}$ using a spectrophotometer (Klein et al., 1971).

Catalase activity (CAT) was determined as the amount of $\mathrm{H}_{2} \mathrm{O}_{2}$ consumed by the soil as described by $\mathrm{Xu}$ and Zheng (1986). Twenty five $\mathrm{ml}$ of $3 \% \mathrm{H}_{2} \mathrm{O}_{2}$ was added to $5 \mathrm{~g}$ soil sample. After incubation at $4^{\circ} \mathrm{C}$ for 30 minutes, $25 \mathrm{ml}$ of $1 \mathrm{M} \mathrm{H}_{2} \mathrm{SO}_{4}$ was added to it. The contents were filtered; $20 \mathrm{ml}$ of $0.5 \mathrm{M} \mathrm{H}_{2} \mathrm{SO}_{4}$ was then added to the $5 \mathrm{ml}$ filtrate. The resulting solution was titrated against $0.005 \mathrm{M} \mathrm{KMnO}_{4}$ to measure the un-reacted $\mathrm{H}_{2} \mathrm{O}_{2}$.

Phenol oxidase (PHE) and peroxidise (PER) activities were measured with L-DOPA (L-3, 4-dihydroxyphenylalanine) as substrate in acetate buffer (Robertson et al., 1999). Phenol oxidase activity was determined by adding $5 \mathrm{ml}$ of $50 \mathrm{mM}$ sodium acetate buffer and $5 \mathrm{ml}$ of $5 \mathrm{mM}$ L-DOPA to $0.5 \mathrm{~g}$ soil sample. After incubation, the solution was centrifuged and the supernatant was measured by absorbance at $460 \mathrm{~nm}$. Control was kept for each sample by adding $5 \mathrm{ml}$ of acetate buffer instead of L-DOPA. For determination of peroxidase activity, $\mathrm{H}_{2} \mathrm{O}_{2}$ was added in addition to L-DOPA, the increment in the absorbance at $460 \mathrm{~nm}$ due to $\mathrm{H}_{2} \mathrm{O}_{2}$ was expressed as the peroxidase activity.

For determination of active microbial biomass carbon (AMBC), $20 \mathrm{~g}$ soil at $60 \%$ WHC was placed in each of two conical flasks. The soil in one flask was amended with nutrients (120 mg glucose, $30 \mathrm{mg}$ yeast extracts, $45 \mathrm{mg} \mathrm{NH} \mathrm{Nl}_{4}, 12 \mathrm{mg}$

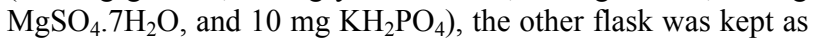
control, without nutrient amendment. A vial containing $5.0 \mathrm{ml}$ of $0.5 \mathrm{M} \mathrm{NaOH}$ was placed in each of the flasks to trap evolved $\mathrm{CO}_{2}$. The flaks were sealed and incubated in the dark for $24 \mathrm{~h}$ at $20^{\circ} \mathrm{C}$. The trapped $\mathrm{CO}_{2}$ was measured by back titration with 0.5 $\mathrm{M} \mathrm{H}_{2} \mathrm{SO}_{4}$. The AMBC was measured as follows:

$$
\mathrm{AMBC}=\left(\mathrm{CO}_{2}-\mathrm{C} 24_{\text {amend }}-\mathrm{CO}_{2}-\mathrm{C} 24_{\text {unamend }}\right) \times \mathrm{AC}
$$

where $\mathrm{CO}_{2}-\mathrm{C} 24_{\text {amend }}-\mathrm{CO}_{2}-\mathrm{C} 24_{\text {unamend }}$ are the amount of $\mathrm{CO}_{2}$ evolved from the glucose-nutrient-amended and unamended soils during $24 \mathrm{~h}$ incubation, respectively, and $\mathrm{AC}$ is the coefficient (0.283) to convert $\mathrm{CO}_{2}-\mathrm{C}$ into $\mathrm{AMBC}$ (Islam and Weil, 2000).

Basal soil respiration (BSR) was measured as the $\mathrm{CO}_{2}$ evolution from the un-amended moist soil adjusted to $60 \%$ WHC for an incubation period of 10 days at $25 \pm 1{ }^{\circ} \mathrm{C}$ in the dark (Islam and Weil, 2000). The BSR was calculated as follows:

$$
\mathrm{BSR}=\left(\mathrm{CO}_{2}-\mathrm{C}_{\text {soil }}-\mathrm{CO}_{2}-\mathrm{C}_{\mathrm{air}}\right) / 10
$$

where $\mathrm{CO}_{2}-\mathrm{C}_{\text {soil }}$ - is the amount of $\mathrm{CO}_{2}$ evolved from soil and $\mathrm{CO}_{2}-\mathrm{C}_{\text {air }}$ is the atmospheric $\mathrm{CO}_{2}$ absorbed by $0.5 \mathrm{M} \mathrm{NaOH}$ in a blank flask.

Metabolic quotient $\left(\mathrm{qCO}_{2}\right)$ was calculated as BSR per unit of AMBC.

\section{Statistical Analysis}

The data were analyzed using a statistical software SYSTAT12. One-way analysis of variance was carried out to compare the means of different treatments and least significant differences at $P<0.05$ were obtained using Duncan's multiple range test (DMRT). The data were also subjected to Pearson correlation analysis, and cluster analysis, to identify the relationship between the variables and to find out the key soil parameters that are sensitive to $\mathrm{Cd}$ exposure.

\section{Results and Discussion}

\section{Soil Enzymes}

DHA activity showed a significant decline $(P<0.05)$ with increase in $\mathrm{Cd}$ concentration (Figure 1 ). And the mean activity decrease was found to be $15,18,35,40$, and $56 \%$ in case of 10 , 20, 50, 100 and $200 \mathrm{mg} / \mathrm{kg} \mathrm{Cd}$ treatments, respectively. The reduction in AMBC (Figure 5) must have contributed to the decrease in DHA as this is a group of intracellular enzyme present in active microorganism in the soil (Nannipieri et al., 1990). The increased sensitivity of DHA to metal contamination can be explained by the fact that the dehydrogenase is active only within living cells, intact, unlike other enzymes that act outside the cell. DHA was found most sensitive to pollution with $\mathrm{Cd}$ (Violeta, 2011). Other reason may be the interaction of heavy metals with the enzyme substrate complex, denaturation of the enzyme protein or interaction of $\mathrm{Cd}$ with protein-active group (Nannipieri et al., 1994). Karaca et al (2002) and others confirm the same pattern in their studies also. Similarly, the inhibition extent was also obvious between different incubation periods, and varied as the incubation proceeded, the highest inhibition rate was detected in at $30^{\text {th }}$ day. Sardar et al (2007) showed that in the case of $\mathrm{Cd}$ treatments, DHA activity was significantly inhibited, after 2 weeks of incubation. This highest inhibitory effect of heavy metals on soil enzyme activities in the first two weeks may be due to the sudden exposure of the microbes to heavy metals. Later on the microbes may have adapted to the polluted environment, and the enzyme activity tended to recover. Similar results were obtained by Maliszews ka-Kordybach and Smreczak, (2003) and Zhang et al. (2007).

Table 1.

Some initial physicochemical characteristics of the soil sample.

\begin{tabular}{clc}
\hline \multicolumn{1}{c}{ Parameters } & value \\
\hline 1 & Clay (\%) & 22.0 \\
2 & Silt (\%) & 9.5 \\
3 & Sand (\%) & 68.5 \\
4 & Bulk density $\left(\mathrm{Mg} / \mathrm{m}^{3}\right)$ & 1.44 \\
5 & Maximum water holding capacity $(\%)$ & 32.54 \\
6 & pH & 4.65 \\
7 & EC (dS/m) & 0.054 \\
8 & LOI (\%) & 4.62 \\
9 & Organic carbon $(\%)$ & 1.69 \\
10 & CEC & 21.3 \\
11 & Nitrogen $(\mathrm{mg} / \mathrm{kg})$ & 19.1 \\
\hline
\end{tabular}


Contrary to DHA, other enzymes like catalase, phenol oxidase, and perioxidase increased significantly $(\mathrm{P}<0.05)$ with increase in Cd concentration (Figure 2). The mean CAT activity has increased by $6,11,22,29$, and $41 \%$ in case of $10,20,50$, 100 and $200 \mathrm{mg} / \mathrm{kg} \mathrm{Cd}$ treatments respectively. Similarly, the corresponding increase in PHE activity was $12,25,31,38$, $51 \%$; and increase in PER was $4,13,20,25,32 \%$ respectively (Figure $3 \& 4$ ). The increase in CAT, PER, and PHE may be due to the increase in production of reactive oxygen species
(ROS) such as hydroxyl radical (HO.), superoxide radical $\left(\mathrm{O}_{2}{ }^{-}\right)$ or hydrogen peroxide $\left(\mathrm{H}_{2} \mathrm{O}_{2}\right)$. Catalase enzyme production and extracellular release may be induced by exposure of the cells to elevated levels of hydrogen peroxide (Ercal et al., 2001). Pereira et al (2002) opined that the reactive oxygen species (ROS) induced by $\mathrm{Cd}$ are metabolised by $\mathrm{CAT}$ in the peroxisomes. Stimulation of CAT activity can be associated with effective antioxidant defense system acting against oxidative stress and/or compensating for the decrease in other antioxidant

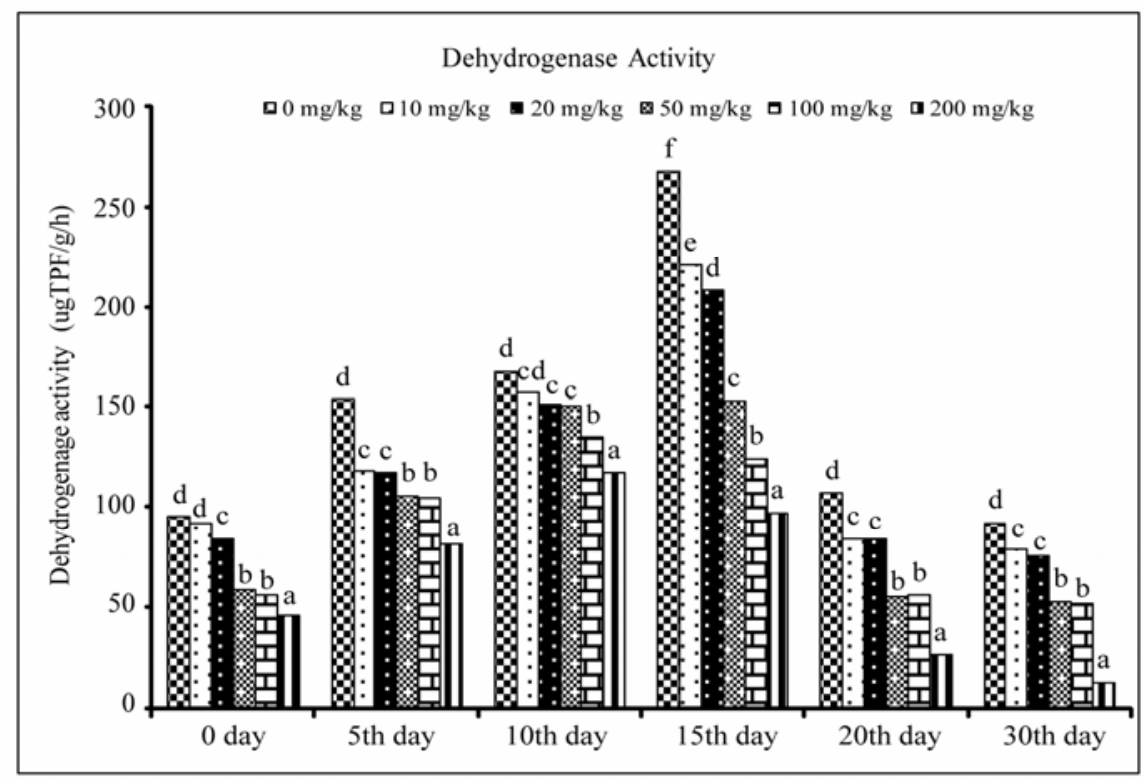

Figure 1.

Changes in dehydrogenase activity of soil added with Cd during the incubation period (Within each incubation period, bars with the same alphabets are not significantly different at $P<0.05$ level using $L S D$.)

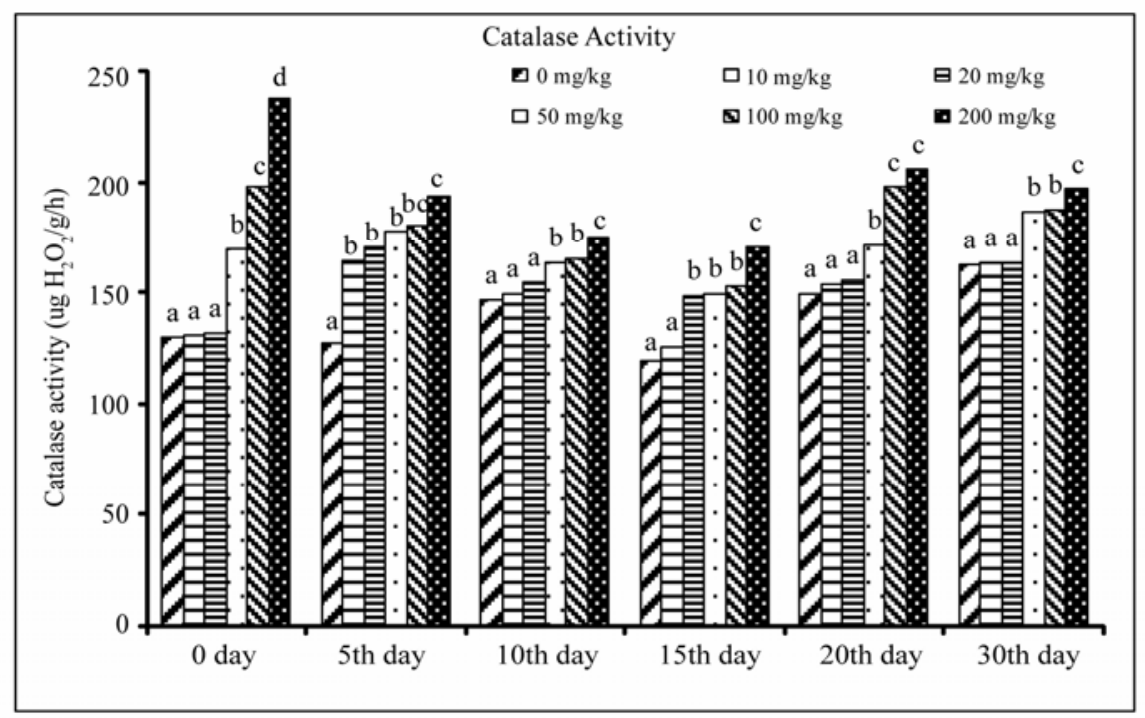

Figure 2.

Changes in catalase activity of soil added with Cd during the incubation period (Within each incubation period bars with the same alphabets are not significantly different at $P<0.05$ level using LSD.) 
enzymes (Radhakrishnan, 2009). Antioxidants are well known to play a prominent role in the defense against free radicals in plants. Catalase scavanges $\mathrm{H}_{2} \mathrm{O}_{2}$ by breaking it down directly to form water and oxygen while peroxidise decomposes $\mathrm{H}_{2} \mathrm{O}_{2}$ by oxidation of phenolic compounds. The increased activities of catalase and peroxidase suggest that soil biological systems depend on these antioxidative enzymes for elimination of $\mathrm{H}_{2} \mathrm{O}_{2}$ under $\mathrm{Cd}$ stress. Effect of $\mathrm{Cd}$ on the above soil enzymes is less found in literature; however, there are reports on such enzymes in plant system. Cui and Wang, (2006) reported an increase in leaf peroxidase activity with $\mathrm{Cd}$ treatments while leaf catalase activity decreased significantly. Similar declines in catalase activity were reported under $\mathrm{Cd}$ stress in rice, cabbage, bean, carrot, radish, and pea (Chaoui et al. 1997; Sandalio et al. 2001; Shah et al. 2001; Pandey and Sharma 2002). However, increased catalase activity was also observed in sunflower cotyledons and barley (Patra and Panda 1998; Gallego et al. 1999) under Cd stress. The effects of Cd on the growth and the activeties of the antioxidant enzymes, catalase, superoxide dismutase and glutathione reductase have been investigated in Crotalaria juncea seedlings, where the CAT activity did not exhibit any major variation in the roots following $\mathrm{CdCl}_{2}$ treatment, however, $2 \mathrm{mM} \mathrm{CdCl} 2$ induced a 6-fold increase in activity in the leaves when compared to the untreated control (Pereira et al., 2002).

\section{Microbial Biomass, Respiration and Metabolic Quotient}

The AMBC values significantly $(\mathrm{p}<0.05)$ decreased with increasing level of $\mathrm{Cd}$ (Figure 5). The mean $\mathrm{AMBC}$ at 0, 10, 20, 50, 100 , and $200 \mathrm{mg} / \mathrm{kg} \mathrm{Cd}$ treatments were $580,471,396,384,362$, and $310 \mathrm{mg} / \mathrm{kg}$, respectively, which corresponds to $19,32,34,38$, and $47 \%$ AMBC reduction. The reduction in $\mathrm{AMBC}$

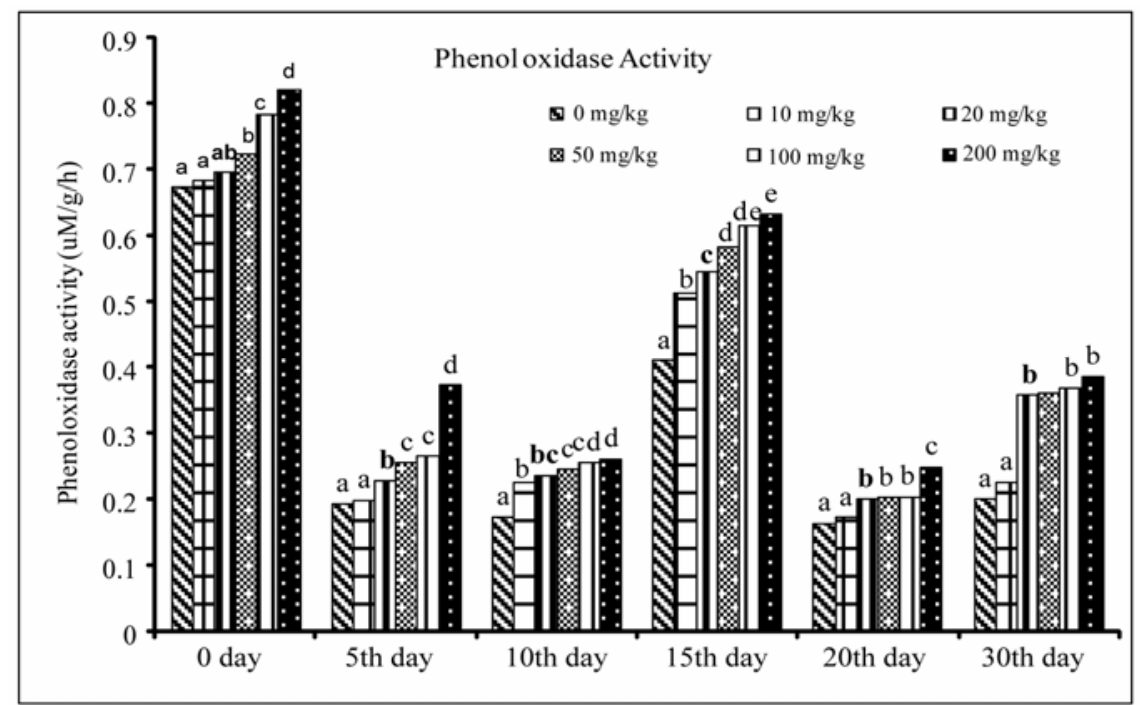

Figure 3.

Changes in phenol oxidase activity of soil added with Cd during the incubation period (Within each incubation period bars with the same alphabets are not significantly different at $P<0.05$ level using LSD.)

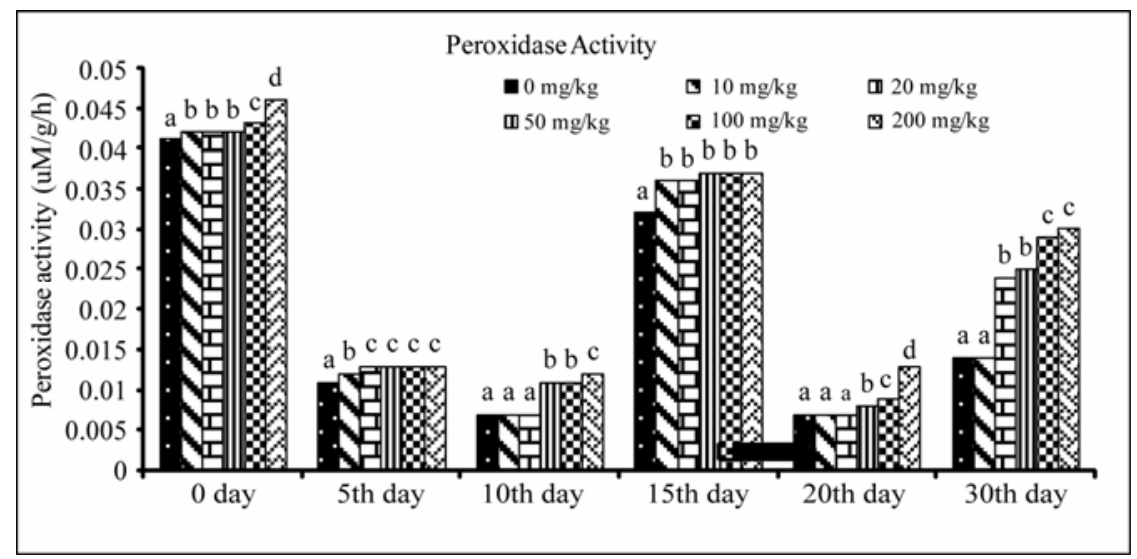

Figure 4.

Changes in peroxidase activity of soil added with Cd during the incubation period (Within each incubation period bars with the same alphabets are not significantly different at $P<0.05$ level using LSD.) 


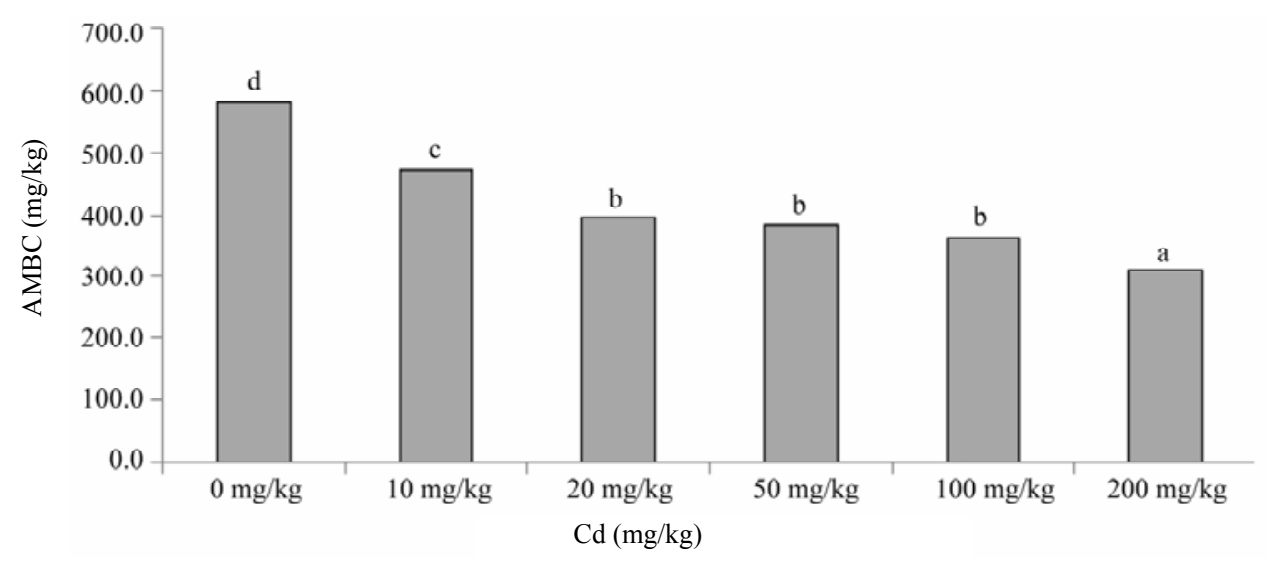

(a)

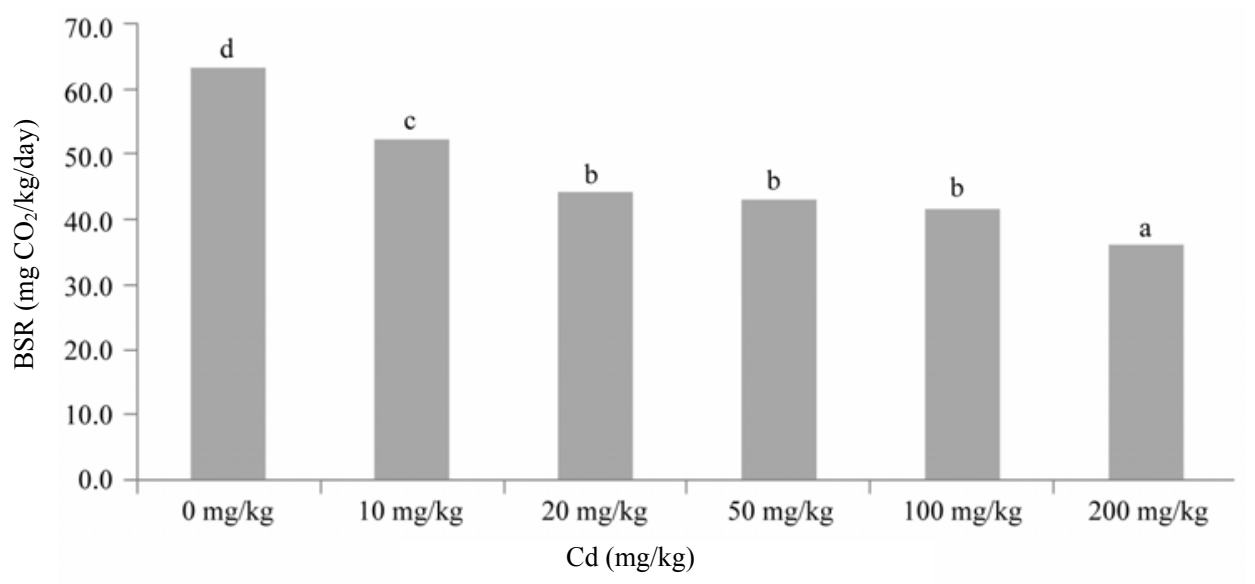

(b)

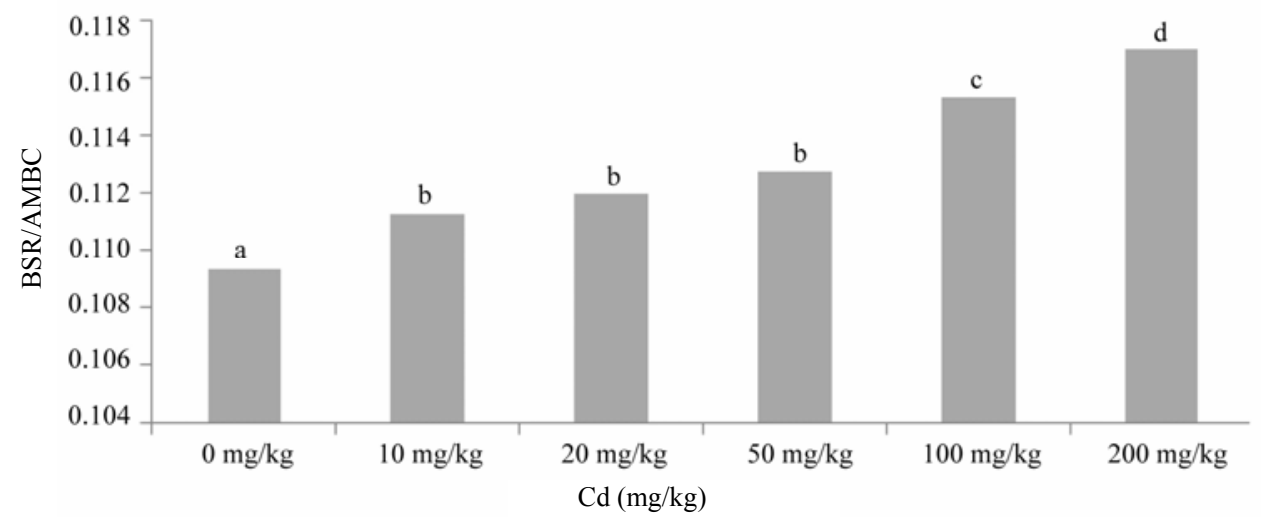

(c)

Figure 5.

Effect of Cd on (a) Active microbial biomass carbon, (b) Basal soil respiration, (c) Metabolic quotient (bars with the same alphabets are not significantly different at $P<0.05$ level using LSD.)

is probably due to the decreased conversion of substrate into new microbial biomass in the $\mathrm{Cd}$ contaminated soils, i.e reduced primary production and resultant lower input of energy (Chander \& Brookes, 1991). Giller et al. (1997) expressed that micro organisms differ in their sensitivity to metal toxicity and sufficient metal exposure will result in immediate death of cells due to disruption of essential functions, and to more gradual changes in population sizes due to changes in viability or competitive ability. According to Zhang et al. (2008), MBC decreased with increasing Cd concentration in soil. These results are in agreement with the findings of previous studies (Bhattacharyya et al. 2008; Khan et al., 2010). But results of Fritze et al., (2000) and Landi et al., (2000) showed that even at high Cd contamination up to $1000 \mathrm{mg} \mathrm{Cd} / \mathrm{kg}$ microbial biomass $\mathrm{C}$ was 
not found to be negatively affected. Results from another study conducted in a laboratory on an agricultural sandy loam showed a significantly lower biomass $\mathrm{C}$ in a $\mathrm{Cd}$ polluted soil at the very low contamination level of $0.001799 \mathrm{mg} \mathrm{Cd} / \mathrm{kg}$ (Griffiths et al., 1997). Giller et al. (1998) reported that the microbial biomass C in agricultural soils under long- term metal stress is reduced in comparison to an unpolluted site. This shows that the comparison of these results is very difficult because the different soil types, time frames, and metal concentrations, lead to different bioavailable fractions of the metals. Moreover $\mathrm{Cd}$ is not an essential element and so cannot have a direct positive influence on the soil microbes. There may be an indirect effect of $\mathrm{Cd}$ on the availability of other essential micronutrients. The different soil types and locations contain different microbial communities which may not have the same sensitivity to Cd toxicity.

Microbial biomass alone does not provide information on microbial activity. Some measure of microbial biomass turnover, such as BSR, is required for this assessment (Anderson and Domsch, 1986; Sparling \& Ross, 1993). The basal respiration decreased by $18,30,32,34$, and $43 \%$ under $10,20,50,100$ and $200 \mathrm{mg} / \mathrm{kg} \mathrm{Cd}$ treatments respectively (Figure 5). The reduction in BSR may be due to the adverse effects of $\mathrm{Cd}$ on soil microflora, which appeared to increase the accumulation of organic matter as the heavy metal content increased, probably because the biomass was less effective in mineralizing soil organic matter under these conditions. Soil respiration studies on forest soils showed a decreasing trend with Cd contamination level. (Landi et al., 2000). The microbial metabolic quotient (respiration-to-biomass ratio) or $\mathrm{qCO}_{2}$ is increasingly being used as an index of ecosystem development (during which it supposedly declines) and disturbance (due to which it supposedly increases) (Wardle \& Ghani, 1995). The mean $\mathrm{qCO}_{2}$ at $0,10,20,50,100$, and $200 \mathrm{mg} / \mathrm{kg} \mathrm{Cd}$ treatments were 0.109 , $0.111,0.112,0.113,0.115$, and $0.117 \mathrm{mg} / \mathrm{kg} /$ day respectively. The metabolic quotient increased by $2,2.7,3.4,5.8$ and $7.4 \%$ under 10, 20, 50, 100, and $200 \mathrm{mg} / \mathrm{kg} \mathrm{Cd}$ treatments respectively (Figure 5). This may be due to the fact that under stress, the soil micro organisms need to expend more energy to survive. The greater demand for energy by microorganisms in order to cope with the toxicity of $\mathrm{Cd}$ was also confirmed by the increase in metabolic quotient $\left(\mathrm{qCO}_{2}\right)$. Chander and Brookes (1991) and Bardgett and Saggar (1994) reported a doubling of $\mathrm{qCO}_{2}$ upon heavy metal contamination. An increased $\mathrm{qCO}_{2}$ indicates shifting of energy from growth to maintenance in an ecosystem. Biomass synthesis is less efficient under heavy metal stress and biomass reduction in heavy metal contaminated soils is mainly due to inefficient biomass synthesis. The shift towards catabolic processes is often better reflected by increased metabolic quotients $\left(\mathrm{qCO}_{2}\right)$, i.e. the ratio of $\mathrm{CO}_{2}$ production rate to microbial biomass.

\section{Correlations and Cluster Analysis}

Significant negative correlation $(\mathrm{P}<0.05)$ was observed between DHA and PHE/ CAT (Table 2), however, positive relation $(\mathrm{P}<0.01)$ was observed between DHA and AMBC/BSR. PHE had significant positive correlation with CAT, and negative relation with $\mathrm{AMBC} / \mathrm{BSR}$. Negative correlation was observed between CAT and AMBC/BSR, and positive correlation with qCO2. AMBC had a significant positive correlation with BSR. The responses to $\mathrm{Cd}$ amendment by different soil pa-

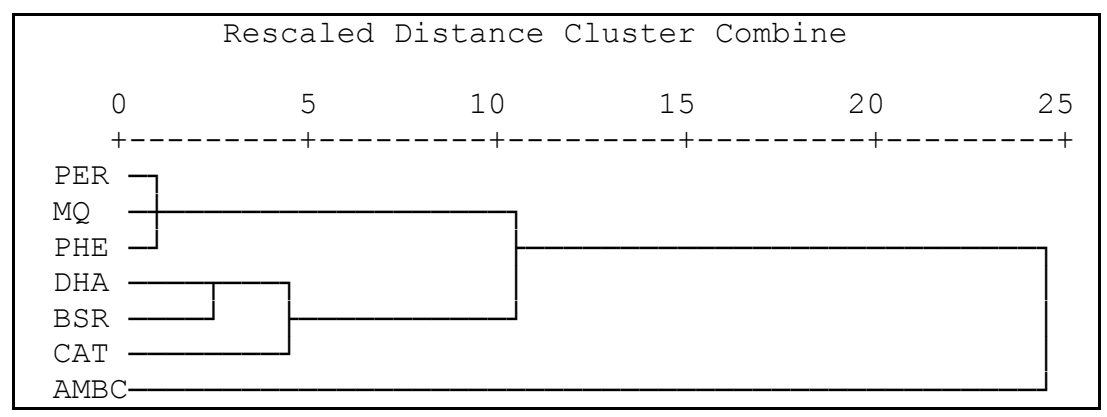

Figure 6.

Hierarchical dendrogram for soil parameters obtained by Ward's hierarchical clustering method.

Table 2.

Correlations between the parameters of soil contaminated with $C d$.

\begin{tabular}{cccccccc}
\hline & DHA & PHE & PER & CAT & AMBC & BSR & $\mathrm{qCO}_{2}$ \\
\hline DHA & 1.00 & $-0.966^{* *}$ & -0.704 & $-0.992^{* *}$ & $0.933^{* *}$ & $0.923^{* *}$ & -0.799 \\
PHE & & 1.00 & 0.662 & $0.961^{* *}$ & $-0.974^{* *}$ & $-0.969^{* *}$ & 0.761 \\
PER & & & 1.00 & 0.724 & -0.549 & -0.539 & 0.632 \\
CAT & & & & 1.00 & $-0.901^{*}$ & $-0.889^{*}$ & $0.854^{*}$ \\
AMBC & & & & & 1.00 & $0.999^{* *}$ & -0.660 \\
BSR & & & & & & 1.00 & -0.637 \\
$\mathrm{qCO}_{2}$ & & & & & & & 1.00 \\
\hline
\end{tabular}

*Correlation is significant at the 0.05 level (2-tailed); **Correlation is significant at the 0.01 level (2-tailed). 
rameters were further classified by cluster analysis. Relatively homogeneous groups of variables were identified by hierarchical cluster analysis, using an algorithm that starts with each variable in a separate cluster and combines clusters. This was done by Ward's method, with Euclidean distances as the criterion to form the clusters. For $\mathrm{Cd}$ amended soils, Figure 6 shows three clusters: 1) PER-PHE-qCO $\mathrm{CO}_{2}$ 2) DHA-BSR-CAT, 3) AMBC. However, the clusters $1 \& 2$ could be joined together at a relatively high level. The group of $\mathrm{AMBC}$ was remarkably different from the other parameters in terms of Euclidian distances in cluster analysis. Judging from these results, the $\mathrm{AMBC}$ appears to be the sensitive indicator for the effects of $\mathrm{Cd}$ on the soil quality. Microbial biomass is well established as an early indicator of gross changes in $\mathrm{C}$ input caused by pollution (Brookes and McGrath, 1984). In ecotoxicological studies, the microbial biomass has been proposed as a sensitive indicator to define the impact of contaminants such as metals on soil biological functioning (Brookes, 1995; Dahlin et al., 1997; Giller et al., 1998).

\section{Conclusion}

The soil biological and biochemical activities significantly altered with the exposure of $\mathrm{Cd}$ as evidenced by the reduction in the AMBC, BSR, and DHA activity; and increase in the activities of CAT, PHE, PER and microbial quotient. AMBC appears to be sensitive soil indicator for the effects that are resulting from $\mathrm{Cd}$ contamination. Further studies involving different types of soils along the natural Cd contamination gradient are needed to clarify the trends detected in this study.

\section{Acknowledgements}

We express our thanks to Director, Central Institute of Mining and Fuel Research, Dhanbad, India for supporting this publication. This work was financially supported under the Net Work Project (NWP-017, XI FYP) of the Council for Scientific and Industrial Research (CSIR), Ministry of Science and Technology, Government of India.

\section{References}

Anderson, T. H., \& Domsch, K. H. (1990). Application of eco-physiological quotients $\left(q \mathrm{CO}_{2}\right.$ and $\left.q \mathrm{D}\right)$ on microbial biomasses from soils of different cropping histories. Soil Biology and Biochemistry, 22, 251-255. doi:10.1016/0038-0717(90)90094-G

Anderson, T. H., \& Domsch, K. H. (1986). Carbon assimilation and microbial activity in soil. Zeitschrift für Pflanzenernärung und Bodenkunde, 149, 457-468. doi:10.1002/jpln.19861490409

Bardgett, R. D., \& Saggar, S. (1994). Effects of heavy metal contamination on the short-term decomposition of labelled $\left[{ }^{14} \mathrm{C}\right]$ glucose in a pasture soil. Soil Biology and Biochemistry, 26, 727-733. doi:10.1016/0038-0717(94)90265-8

Bhattacharyya, P., Tripathy, S., Chakrabarti, K., Chakraborty, A., \& Banik, P. (2008). Fractionation and bioavailability of metals and their impacts on microbial properties in sewage irrigated soil. Chemosphere, 72, 543-550. doi:10.1016/j.chemosphere.2008.03.035

Bramley, R. V. (1990). Cadmium in New Zealand agriculture. New Zealand Journal of Agric Research, 33, 505-519.
Brookes, P. C. (1995). The use of microbial parameters in monitoring soil pollution by heavy etals. Biology and Fertility of Soils, 19, 269-279. doi:10.1007/BF00336094

Brookes, P. C., \& McGrath, S. P. (1984). Effects of metal toxicity on the size of the soil microbial biomass. Journal of Soil Science, 35, 341-346. doi:10.1111/j.1365-2389.1984.tb00288.x

Chander, K., \& Brookes, P. C. (1991). Microbial biomass dynamics during the decomposition of glucose and maize in metal-contaminated and non-contaminated soils. Soil Biology and Biochemistry, 23, 917-925. doi:10.1016/0038-0717(91)90171-F

Chaoui, A., Mazhoudi, S., Ghorbal, M. H., \& Ferjani, E. (1997). Cadmium and zinc induction of lipid peroxidation and effects on antioxidant enzyme activities in bean (Phaseolus vulgaris L.). Plant Science, 127, 139-147. doi:10.1016/S0168-9452(97)00115-5

Christensen, G. M., Olson, D., \& Riedel, B. (1982). Chemical effects on the activity of eight enzymes. A review and a discussion relevant to environmental monitoring. Environmental Research, 29, 247-254. doi:10.1016/0013-9351(82)90026-3

Cui, Y., \& Wang, Q. (2006). Physiological responses of maize to elemental sulphur and cadmium stress. Plant, Soil and Environment, 52, 523-529.

Dahlin S., Witter E., Martensson A., Turner A., \& Baath A. (1997). Changes in the microbiological properties of agricultural soils at low levels of metal contamination. Soil Biology \& Biochemistry, 29, 1405-1415. doi:10.1016/S0038-0717(97)00048-5

Doran, J. W., \& Parkin, T. B. (1994). Defining and assessing soil quality. In J. W. Doran, D. C. Coleman, D. F. Bezdicek, and B. A. Stewart, (Eds.), Defining soil quality for a sustainable environment (pp. 3-21). Madison, WI: Soil Science Society of America.

Ercal, N., Gurer-Orhan, H., \& Aykin-Burns, N. (2001). Toxic metals and oxidative stress part I: Mechanisms involved in metal-induced oxidative damage. Current Topics in Medicinal Chemistry, 1, 529539. doi:10.2174/1568026013394831

Frankenberger, W. T. Jr., Johanson, J. B., \& Nelson, C. O. (1983). Urease activity in sewage sludge-amended soils. Soil Biology and Biochemistry, 15, 543-551. doi:10.1016/0038-0717(83)90048-2

Fritze, H., Perkiomaki, J., \& Saarela, U. (2000). Effect of Cd containing wood ash on the microflora of coniferous forest humus. FEMS Microbiology Ecology, 32, 43-51. doi:10.1111/j.1574-6941.2000.tb00697.x

Gallego, S. M., Benavides, M. P., \& Tomaro, M. L. (1999). Effect of cadmium ions on antioxidant defense system in sunflower cotyledons. Biology Plant, 42, 49-55. doi:10.1023/A:1002159123727

Giller, K. E., Beare, M. H., Lavelle, P., Izac, A. M. N., \& Swift, M. J. (1997). Agricultural intensification, soil bio-diversity and ecosystem function. Applied Soil Ecology, 6, 3-16. doi:10.1016/S0929-1393(96)00149-7

Giller, K., Witter, E., \& McGrath, S. (1998). Toxicity of heavy metals to microorganisms and microbial processes in agricultural soils: A review. Soil Biology and Biochemistry, 30, 1398-1414. doi:10.1016/S0038-0717(97)00270-8

Griffiths, B., Díaz-Raviña, M., Ritz, K., McNicol, J., Ebblewhite, N., \& Baath, E. (1997). Community DNA hybridisation and communities from heavy metal polluted soils. FEMS Microbiology Ecology, 24, 103-112. doi:10.1111/j.1574-6941.1997.tb00427.x

Huang, C. Y., \& Khan, K. S. (1998). Effects of cadmium, lead and their interaction on the size of microbial biomass in a red soil. Soil Environment, 1, 227-236.

Islam, K. R., \& Weil, R. R. (2000). Land use effects on soil quality in a tropical forest ecosystem of Bangladesh. Agriculture, Ecosystem \& Environment, 79, 9-16. doi:10.1016/S0167-8809(99)00145-0 
Kandeler, E., Tscherko, D., \& Spiegel, H. (1999). Long-term monitoring of microbial biomass, $\mathrm{N}$ mineralisation and enzyme activities of a chernozem under different tillage management. Biology and Fertility of Soils, 28, 343-351. doi:10.1007/s003740050502

Karacaa, A., David, C. N., \& James, M. L. (2002). Effect of cadmium-contamination with sewage sludge and phosphate fertiliser amendments on soil enzyme activities, microbial structure and available cadmium. Biology and Fertility of Soils, 5, 428-434. doi:10.1007/s00374-002-0490-4

Khan, M. S., Zaidi, A., Ahemad, M., Oves, M., \& Wani, P. A. (2010). Plant growth promotion by phosphate solubilizing fungi-current perspective. Archives of Agronomy and Soil Science, 56, 73-98. doi:10.1080/03650340902806469

Klein, D. A., Loh, T. C., \& Goulding, R. L. (1971). A rapid procedure to evaluate dehydrogenase activity of soils low in organic matter. Soil Biology and Biochemistry, 3, 385-387. doi:10.1016/0038-0717(71)90049-6

Landi, L., Renella, G., Moreno, J., Falchini, L., \& Nannipieri, P. (2000). Influence of cadmium on the metabolic quotient, L-, D-glutamine acid respiration ratio and enzyme activity, microbial biomass ratio under laboratory conditions. Biology and Fertility of Soils, 32, 8-16. doi:10.1007/s003740000205

Lebedeva, L. A., Lebedev, S. N., \& Edemskaya, N. L. (1995). The effect of heavy metals and lime on urease activity in soddy-podzolic soil. Moscow University Soil Science Bulletin, 50, 53-61.

Loganathan, P., Hedley, M. J., Gregg, P. H., \& Currie, L. D. (1996). Effect of phosphate fertiliser type on the accumulation and plant availability of cadmium in grassland soils. Nutrient Cycling in Agroecosystems, 46, 169-178. doi:10.1007/BF00420551

Maliszewska-Kordybach, B. \& Smreczak, B. (2003). Habitat function of agricultural soils affected by heavy metals and polycyclic aromatic hydrocarbons contamination. Environment International, 28, 719728. doi:10.1016/S0160-4120(02)00117-4

Milosevic, N., Govedarica, M., Jarak, M., Petrovic, N., Jevtic, S., \& Lazic, B. (1997). The effect of heavy metals on total soil microbiological activity in lettuce. Acta Horticulture, 462, 133-142.

Nannipieri, P., Badalucco, L., Landi, L., \& Pietramellara, G. (1997). Measurement in assessing the risk of chemicals to the soil ecosystem. In J. T. Zelikoff (ed)., Ecotoxicology: Responses, biomarkers and risk assessment. An OECD workshop. (pp. 507-534). Fair Haven, NJ: SOS Publications.

Nannipieri, P., Gregos, S., \& Ceccanti, B. (1990). Ecological significance of the biological activity in soil. Soil Biology and Biochemistry, 6, 293-354.

Pandey, N., \& Sharma, C. P. (2002). Effect of heavy metals $\mathrm{Co}^{2+}, \mathrm{Ni}^{2+}$ and $\mathrm{Cd}^{2+}$ on growth and metabolism of cabbage. Plant Science, 163, 753-758. doi:10.1016/S0168-9452(02)00210-8

Patra, J., \& Panda, B. B. (1998). A comparison of biochemical responses to oxidative and metal stress in seedlings of barley, Hordeum vulgare L. Environmental Pollution, 101, 99-105. doi:10.1016/S0269-7491(98)00009-8

Pereira, G. J. G., Molina, S. M. G., Lea, P. J., \& Azevedo, R. A. (2002). Activity of antioxodant enzymes in response to cadmium in crotalaria juncea. Plant and Soil, 239, 123-132. doi:10.1023/A:1014951524286

Radhakrishnan, M. (2009). Effect of cadmium on catalase activity in four tissues of freshwater fish Heteropneustes fossilis. The Internet Journal of Veterinary Medicine, 7.
Robertson, G. P., Coleman, D. C., Bledsoe, C. S., \& Sollin, P. (1999). Standard soil methods for long term ecological research. Oxford: Oxford University Press.

Sandalio, L. M., Dalurzo, H. C., Gomez, M., Romero-Puertas, M. C., \& del Rio, L. A. (2001). Cadmium-induced changes in the growth and oxidative metabolism of pea plants. Journal of Experimental Botany, 52, 2115-2126.

Sardar, K., Qing, C., El-Latif, H. A., Yue, X., \& Ji-Zheng, H. (2007). Soil enzymatic activities and microbial community structure with different application rates of $\mathrm{Cd}$ and $\mathrm{Pb}$. Journal of Environmental Sciences, 19, 834-840. doi:10.1016/S1001-0742(07)60139-9

Shah, K., Kumar, R. G., Verma, S., \& Dubey, R. S. (2001). Effect of cadmium on lipid peroxidation, superoxide anion generation and activities of antioxidant enzymes in growing rice seedlings. Plant Science, 161, 1135-1141. doi:10.1016/S0168-9452(01)00517-9

Sparling, G. P., \& Ross, D. J. (1993). Biochemical methods to estimate soil microbial biomass: current developments and applications. In K. Mulangoy and R. Merckx (Eds), Soil organic matter dynamics and sustainability of tropical agriculture (pp. 21-37). Chichester: Wiley.

Sparling, G. P. (1997). Soil microbial biomass, activity and nutrient cycling as indicators of soil health. In C. E. Pankhurst, B. M. Doube and V. V. S. R. Gupta (Eds.), Biological indicators of soil health (pp. 97-119). Wallingford: CAB International.

Szili-Kovács, T., Anton, A., \& Gulyás, F. (1999). Effect of Cd, Ni and $\mathrm{Cu}$ on some microbial properties of a calcareous chernozem soil. Proceedings of 2nd Sympossium on the Pathways and Consequences of the Dissemination of Pollutants in the Biosphere, Prague: Ceska Zemedelska Univiversity, 88-102

Violeta, S. C. (2011). Indicator microorganisms of environmental polution. Ph.D. Thesis, Cluj-Napoca: Babeş-Bolyai University.

Wardle, D. A., \& Ghani, A. (1995). A critique of the microbial metabolic quotient $\left(q \mathrm{CO}_{2}\right)$ as a bioindicator of disturbance and ecosystem development. Soil Biology and Biochemistry, 27, 1601-1610. doi:10.1016/0038-0717(95)00093-T

Welp, G. (1999). Inhibitory effects of the total water-soluble concentrations of nine different metals on the dehydrogenase activity of a loess soil. Biology and Fertility of Soils, 30, 132-139. doi:10.1007/s003740050599

Wyszkowska, J., Kucharski, J., Jastrzebska, E., \& Hlasko, A. (2001). The biological properties of the soil as influenced by chromium contamination. Polish Journal of Environmental Studies, 10, 175-183

Xu, G. H., Zheng, H. Y. (1986). Handbook of analysis of soil microorganisms. Beijing: Agriculture Press.

Yao, H., He, Z., Wilson, M. J., \& Campbell, C. D. (2000). Microbial biomass and community structure in a sequence of soils with increasing fertility and changing land use. Microbial Ecology, 40, 223-237.

Zhang, H., Dang, Z., \& Yao, L. X. (2007). Eco-toxicologic effect of cadmium and pyrene combined and simplex pollution on soil microbe. (in Chinese). Journal of Agro-Environment Science, 26, 2225- 2230.

Zhang, N. L., Wan, S. Q., Li, L. H., Bi, J., Zhao, M. M., \& Ma, K. P. (2008). Impacts of urea $\mathrm{N}$ addition on soil microbial community in a semi-arid temperate steppe in northern China. Plant and Soil, 311, 19-28. doi:10.1007/s11104-008-9650-0

Zheng, C. R., Tu, C., \& Chen, H. M. (1999). Effect of combined heavy metal pollution on nitrogen mineralization potential, urease and phosphatase activities in a typic udic ferrisol. Pedosphere, 9, 251-257. 